\title{
Effect of growth stage on fodder yield and nutrient qualities of dual purpose sorghum
}

\author{
PATRICK GITHUI MWANGI ${ }^{1, \boldsymbol{}}$, CHARLES K. GACHUIRI ${ }^{2}$, P.N. MBUGUA $^{2}$ \\ ${ }^{1}$ Kenya Agricultural and Livestock Organization (KALRO). Kaptagat Rd, Nairobi, Kenya Tel.: +254 722 206986, •email: githuiwamwangi@yahoo.com \\ ${ }^{2}$ Department of Animal Production, Faculty of Veterinary Medicine, College of Agriculture and Veterinary Sciences, University of Nairobi. P.O. Box \\ 29053-00625, Kangemi, Nairobi. `email: gachuiri@uonbi.ac.ke
}

Manuscript received: 4 November 2017. Revision accepted: 23 December 2017.

\begin{abstract}
Mwangi PG, Gachuiri CK, Mbugua PN. 2017. Effect of growth stage on fodder yield and nutrient qualities of dual purpose sorghum. Trop Drylands 1: 100-104. The reduction of land for dairy and fodder production necessitates dual purpose crops that fulfill the needs for livestock feed and cereals for human consumption. This study aimed to investigate the yield and nutrient qualities of Improved Dual Purpose Sorghum (IDPS) (Sorghum bicolor-Var Ikinyaruka) at six physiological growth stages. Six treatments based on sorghum growth's physiological stage were randomly administered to the plot in a block and replicated three times. The treatments were IDPS yielded at bloom stage (PS1), soft dough stage (PS2), hard dough stage (PS3), physiological maturity stage (stalks with grains), (PS4), physiological maturity stage (stalks without grains) (PS5), and 1 month post grain reap (PS6). The parameters monitored were Dry Matter (DM) crop, Crude Protein (CP), Neutral Detergent Fiber (NDF), Acid Detergent Fiber (ADF), Acid Detergent Lignin (ADL), In vitro Dry Matter Digestibility (IVDMD) and shoot count. The highest DM crop (18.0 ton/ha) was achieved at PS4 secernated with 8.69, 12.75, 16.2717 .04 and 13.04 ton/ha for PS1, PS2, PS3, PS5 and PS6, respectively. CP reduced with maturity from 8.6 at PS1 to 7.98, 7.96, 7.61, and 6.77 to 6.72 at PS2, PS3, PS4, PS5 and PS6, respectively. NDF and ADF at PS1, PS2, PS3, PS4, PS5 and PS6 were $54.4,60.8,65.71,65.93,66.7370 .3$ and 27.93, 35.96, 41.98, 41.97, 42.04, 46.05, respectively. ADL was 3.44, 5.03, 7.38, 7.39, 7.42, and 8.3 for PS1, PS2, PS3, PS4, PS5 and PS6, respectively. Highest fodder IVDMD of 60.72 was at PS1 secernated with 60.12, 54.73, 53.82, 53.56 and 45.75 achieved at PS2, PS3, PS4, PS5 and PS6, respectively. The PS3 growth stage yielded fodder material with highest nutritive value while highest fodder yields were achieved at PS4. Reaping at PS5 supplied both fodder and grains for livestock and human consumption respectively. It was proven that crop and quality of IDPS were affected by age at reaping time.
\end{abstract}

Keywords: Dual purpose, fodder, growth stage, sorghum

\section{INTRODUCTION}

Grasslands and fodder are the main feed source for dairy cattle production in sub-Saharan Africa. Their availability is highly dependent on rain, which is sufficient during the rainy season but is inadequate during the dry season (KMDP 2013). Accordingly, milk production follows a similar seasonal pattern in response to feeding availability (Le Van 2003). Unfortunately, small-scale farmers rarely stock feed sources for dry-season feeding, due to limited knowledge of conservation technologies and reduced land size for overproduction of livestock feed (KMDP 2013).

In Kenya, dairying work is mainly performed in medium and high potential areas in which increasing population pressure has reduced the average farm size to below 1.2 acres (Nandwa et al. 2013). This indicates that the areas for fodder production are gradually replaced by cultivation of food crops in response to population growth (Shem et al. 2001). Commercial crops, such as coffee and tea, also compete in the same space with fodder so the availability of human food and animal feedstock is a problem for the majority of farming families (KMDP 2013). To overcome this problem, there is a need to identify dual purpose crops with high production per unit area of feed for livestock rearing and cereals for human consumption.

Improved dual purpose sorghum (IDPS) variety Ikinyaruka matches with such requirements because it is able to supply grain and sufficient feed throughout the year when reaped at different growth stages (Gachuki et al. 2007). However, the yield and quality of feed at this stage of crop are unknown. Hence, to measure the effect of growth stage at reaping time of IDPS on DM crops and the nutritive value of the feed was the main objective of this study.

\section{MATERIALS AND METHODS}

The study was performed at Kenya Agricultural and Livestock Research Organization (KALRO) station in Lanet, Nakuru County, Kenya. The station is situated at altitude of $1920 \mathrm{~m}$ above sea level (m asl). The area is located in ecological zone $1 \mathrm{~V}$ with long rains being received from the month of March to June and short rains in the months of October, November and December. Annual rainfall is often below $800 \mathrm{~mm}$ and unreliable both in quantity and distribution. Temperatures range between 8 to $30^{\circ} \mathrm{C}$. Soils are deep sandy loam with good water holding capability and a $\mathrm{pH}$ range of 5.5 to 6.5 . 
The experimental field was plowed and hallowed prior to the onset of the rains. Large clods of soil were broken into finer particles using hoes and rakes to attain a fine tilth. Dual purpose sorghum seeds (Ikinyaruka) were sown in a three block experimental plot containing eighteen plots using a completely randomized block design. Each block would have six plots in $5 \times 4.8$ meters measurement.

Treatments were bloom stage (PS1), soft dough stage (PS2), hard dough stage (PS3), physiological maturity stage (stalks with grains), (PS4), physiological maturity stage (stalks without grains) (PS5), and 1month post grain reap (PS6). Shallow rows with a space of $60 \mathrm{~cm}$ were dug and Di-Ammonium Phosphate (DAP) fertilizer was applied at a rate of $80 \mathrm{~kg} / \mathrm{ha}$ and mixed with the soil thoroughly. Certified seeds were drilled in the rows at a rate of 6-8 $\mathrm{kg} / \mathrm{ha}$ and covered with a thin layer of soil. Thinning was done when the crop was $20 \mathrm{~cm}$ aboveground to achieve inter plant spacing of $20 \mathrm{~cm}$. After thinning, top dressing was done using CAN fertilizer at a rate of $80 \mathrm{~kg} / \mathrm{ha}$. Weed control was done manually during the growth period. Pesticides were used to control pests and diseases.

Before reaping, the growth stage is carefully observed and the number of days after sowing is carefully noted. PS1 was reaped at 87 days after sowing at the time it is estimated that half the plants in the net plot had panicles carrying about $50 \%$ of flowers. PS2 at 115 days at the time panicles had $50 \%$ of soft milky grains, PS3 at 142 days at the time panicles had $50 \%$ of hard grains. PS4 at 169 days at the time panicles had $50 \%$ of mature grains. PS5 was reaped 169 days after removal of panicles, while PS6 was reaped 1 month after the grain reap. Reaping and sampling were performed on whole plant except at PS5 and PS6 where main stalk panicles had been cut for grain reaping. A net plot of $3.0 \times 4.0$ meters was assessed within the six middle rows of each plot leaving 0.5 meters on either side of the row to cushion the border effect.

Calibrated measuring iron bar was used to measure height of all plants in the plot while shoots were counted physically. Stalks within the plots were reaped (cut) at height of 3 inches above the ground for each growth stage and their fresh weight was noted. Reaped stalks were then chopped using a machete into small irregular pieces of about $2-3 \mathrm{~cm}$ in size and mixed thoroughly on a plastic sheet spread on the ground. Approximately $1 \mathrm{~kg}$ sample of the chopped material was placed in an air-dry oven for 3 days at a temperature of $60^{\circ} \mathrm{C}$ for fresh fodder dry matter (DM) specification. After reaping at PS1, farmyard manure was applied to reaped plot and ratoon crop was allowed to grow. The ratoon crop was later reaped at bloom stage and subjected to similar sampling and data collection procedures. Grains reaped at PS5 were sun-dried to a moisture value of approximately $12.5 \%$ and their dry weight was recorded. Samples of dried fresh stalk were ground in the Wiley Mill to pass a $1 \mathrm{~mm}$ screen for subsequent DM and nutrient analysis.

Fresh fodder yield was achieved by weighing freshly reaped material from each plot and the yield was stated in $t$ $\mathrm{ha}^{-1}$. Similarly, dry matter (DM) and grain from each plot were stated in $\mathrm{t} \mathrm{ha}^{-1}$. Dry matter value of forage was specified by placing an air dried sample in an oven at $105^{\circ} \mathrm{C}$ overnight, cooled in a desiccator and weight recorded. Nitrogen concentrations were specified by the Kjeldahl procedure (AOAC 1990). NDF, ADF and ADL were analyzed according to the sequential method of Van Soest et al. (1991). IVDMD was specified in accordance with the two-stage fermentation technique of Tilley and Terry (Tilley and Terry 1963). Analysis of variance was done using the GLM procedure of SAS Statistical Software Version 9.1. Effects were considered significant in all statistical calculations if the $\mathrm{P}$-values were $<0.05$. Means were separated using Fisher's Least Significant Difference (LSD) test.

\section{RESULTS AND DISCUSSION}

The number of shoots, dry matter value and yields accrued $(\mathrm{P}<0.05)$ with advancing age of the plant (Table 1). Mean shoot counts per plant were 2.60, 2.76, 3.86, 3.87, 3.89 and 3.92 for PS1, PS2, PS3, PS4, PS5 and PS6, respectively. The dry matter values were 21.00 25.30, 27.30, 29.91, 28.90 and 26.19 for PS1, PS2, PS3, PS4, PS5 and PS6, respectively. DM value was lowest at PS1, accrued significantly at PS2 and was highest and similar at PS3, PS4 and PS5. The DM yields for PS1, PS2, PS3, PS4, PS5 and PS6 stages were 8.69, 12.75, 16.27, 18.01, 17.04, and 13.05 t/ ha, respectively. Highest DM yields of 16.27, 18.01 and $17.04 \mathrm{t} / \mathrm{ha}^{-1}$ were achieved at PS3, PS4 and PS5 growth stages, respectively and coincided with the highest DM value of the crop.

The crude protein NDF, ADF, ADL, Ash and IVDMD of forage were significantly $(\mathrm{P}<0.05)$ affected by stage at reap (Table 2). CP value was 8.60, 7.98, 7.96, 7.61, 6.77 and 6.72 for PS1, PS2, PS3, PS4, PS5 and PS6, respectively, reducing with the advancing age of the crop. Highest CP value of 8.60 was achieved at PS1 then reduced to less than 7 after grain reap.

NDF values were, 54.4, 60.8, 65.71, 65.93, 66.73 and 70.3 for PS1, PS2, PS3, PS4, PS5 and PS6, respectively. ADF values were, 27.93, 35.96, 41.98, 41.97, 42.04 and 46.05 for PS1, PS2, PS3, PS4, PS5 and PS6, respectively while ADL was 3.44, 5.03, 7.38, 7.39, 7.42, and 8.3 for PS1, PS2, PS3, PS4, PS5 and PS6, respectively.

Table 1. Shoot count and yields of IDPS at six different physiological growth stages

\begin{tabular}{|c|c|c|c|}
\hline Growth stage & $\begin{array}{l}\text { Shoots/ } \\
\text { plant }\end{array}$ & $\begin{array}{l}\text { DM } \\
\text { value }\end{array}$ & $\begin{array}{l}\text { DM yield } \\
\left(\mathrm{t} / \mathrm{ha}^{-1}\right)\end{array}$ \\
\hline Bloom stage (PS1) & $2.60^{\mathrm{a}}$ & $21.00^{\mathrm{a}}$ & $8.69^{\mathrm{a}}$ \\
\hline Soft dough (PS2) & $2.76^{\mathrm{a}}$ & $25.03^{b}$ & $12.75^{\mathrm{b}}$ \\
\hline Hard dough stage (PS3) & $3.86^{\mathrm{b}}$ & $27.30^{c}$ & $16.27^{\mathrm{c}}$ \\
\hline $\begin{array}{l}\text { Physiological grain maturity } \\
\text { (stalks with grains) (PS4) }\end{array}$ & $3.87^{\mathrm{b}}$ & $29.91^{\mathrm{c}}$ & $18.01^{\mathrm{c}}$ \\
\hline $\begin{array}{l}\text { Physiological grain maturity } \\
\text { (stalks without grains) (PS5) }\end{array}$ & $3.89^{\mathrm{b}}$ & $28.90^{c}$ & $17.04^{c}$ \\
\hline 1 month post grain reap (PS6) & $3.92^{\mathrm{b}}$ & $26.19^{\mathrm{b}}$ & $13.05^{\mathrm{b}}$ \\
\hline SEM & 0.849 & 0.63 & 0.001 \\
\hline Stage effect & $*$ & $*$ & $*$ \\
\hline
\end{tabular}

Note: ${ }^{a, b, c}$, : Means within the same column with different superscripts differ significantly $(\mathrm{P}<0.05)$ * ${ }^{*}$ Significant effect $(\mathrm{P}$ $<0.05)$. SEM = standar error of the mean 
Table 2: Nutrient composition of IDPS reaped at different growth stages

\begin{tabular}{|c|c|c|c|c|c|c|}
\hline \multirow{2}{*}{ Growth stages } & \multicolumn{6}{|c|}{$\% \mathrm{DM}$} \\
\hline & $\mathbf{C P}$ & NDF & ADF & ADL & ASH & IVDMD \\
\hline Bloom stage (PSI) & $8.60^{\mathrm{d}}$ & $54.40^{\mathrm{a}}$ & $27.93^{\mathrm{a}}$ & $3.44^{\mathrm{a}}$ & $8.52^{\mathrm{d}}$ & $60.72^{c}$ \\
\hline Soft dough (PS2) & $7.98^{c}$ & $60.80^{\mathrm{b}}$ & $35.96^{\mathrm{b}}$ & $5.03^{\mathrm{b}}$ & $8.50^{\mathrm{d}}$ & $60.12^{\mathrm{c}}$ \\
\hline Hard dough (PS3) & $7.96^{\mathrm{c}}$ & $65.71^{\mathrm{c}}$ & $41.98^{c}$ & $7.38^{c}$ & $7.90^{c}$ & $54.73^{b}$ \\
\hline Physiological grain maturity (stalks with grains) (PS4) & $7.61^{\mathrm{b}}$ & $65.93^{\mathrm{c}}$ & $41.97^{\mathrm{c}}$ & $7.39^{c}$ & $7.09^{\mathrm{c}}$ & $53.82^{\mathrm{b}}$ \\
\hline Physiological grain maturity (stalks without grains) (PS5) & $6.77^{\mathrm{a}}$ & $66.73^{\mathrm{c}}$ & $42.04^{\mathrm{c}}$ & $7.42^{\mathrm{c}}$ & $6.48^{b}$ & $53.56^{\mathrm{b}}$ \\
\hline 1 month post grain reap (PS6) & $6.72^{\mathrm{a}}$ & $70.30^{\mathrm{d}}$ & $46.05^{\mathrm{d}}$ & $8.30^{\mathrm{d}}$ & $6.21^{\mathrm{a}}$ & $45.75^{\mathrm{a}}$ \\
\hline SEM & 0.31 & 1.42 & 1.22 & 0.32 & 0.24 & 0.66 \\
\hline Stage effect & $*$ & $*$ & $*$ & $*$ & $*$ & $*$ \\
\hline
\end{tabular}

Note: a,b,c,d: Means in the same column followed by different superscripts differ significantly at $\mathrm{P}<0.05$. * $=$ Significant effect (at $\mathrm{P}<$ 0.05 ) of growth stage. NS $=$ Lack of significant effect of growth stage, at $\mathrm{P}<0.05$. SEM $=$ standard error of the mean.

Table 4. Growth parameters and yields of ratoon crop secernate with parent crop at PS1 growth stage

\begin{tabular}{lcccc}
\hline \multicolumn{1}{c}{ Growth stages } & Plant height $(\mathbf{c m})$ & Shoots/ plant & DM\% & DM yield (t/ha $\left.\mathbf{~}^{-\mathbf{1}}\right)$ \\
\hline PS1-Ratoon crop & $100.78^{\mathrm{a}}$ & $5.18^{\mathrm{b}}$ & $24.21^{\mathrm{b}}$ & $9.54^{\mathrm{b}}$ \\
PS1-Parent crop & $130.36^{\mathrm{b}}$ & $2.60^{\mathrm{a}}$ & $21.00^{\mathrm{a}}$ & $9.10^{\mathrm{a}}$ \\
SEM & 3.980 & 0.142 & 0.117 & 0.114 \\
Stage effect & $*$ & $*$ & $*$ & $*$ \\
\hline
\end{tabular}

Note: a,b: Means in the same column followed by different superscripts differ significantly at $\mathrm{P}<0.05$. * $=$ Significant effect $($ at $\mathrm{P}<$ 0.05 ) of growth stage. SEM = standard error of the mean

Table 5. Nutrient composition of IDPS ratoon crop at PS1 growth stage

\begin{tabular}{|c|c|c|c|c|c|c|}
\hline \multirow{2}{*}{ Growth stages } & \multicolumn{6}{|c|}{$\% \mathrm{DM}$} \\
\hline & $\mathbf{C P}$ & NDF & ADF & ADL & ASH & IVDMD \\
\hline (PS1) Ratoon & 8.48 & 53.95 & 27.90 & 3.33 & 8.98 & 60.69 \\
\hline (PS1) parent crop & 8.60 & 54.40 & 27.93 & 3.44 & 8.52 & 60.72 \\
\hline SEM & 0.209 & 0.741 & 0.598 & 0.035 & 0.035 & 0.209 \\
\hline Ratoon effect & NS & NS & NS & NS & NS & NS \\
\hline
\end{tabular}

Note: NS = Lack of significant effect, SEM = standard error of the mean

Ash values for PS1, PS2, PS3, PS4, PS5 and PS6 stages were 8.52, 8.5, 7.9, 7.09, 6.48 and 6.21 for PS1, PS2, PS3, PS4, PS5 and PS6, respectively. In vitro dry matter digestibility values were $60.72,60.12,54.73,53.82,53.56$ and 45.75 for PS1, PS2, PS3, PS4, PS5 and PS6, respectively, and reduced with plant age.

Plant height $(\mathrm{cm})$, shoots count, forage and DM yield $\left(\mathrm{t} / \mathrm{ha}^{-1}\right)$ of ratoon secernated with parent crop is shown in Table 4. Parent crop was taller $(\mathrm{P}<0.05)$ than the ratoon crop while the latter had more shoots. Ratoon crop had higher DM yield than parent crop in agreement with Irungu et al. (1993).

Nutrient composition of ratoon crop and parent crop (PS1) is shown in Table 5. There was no difference ( $p>$ 0.05 ) in nutrient composition between the two crops.

\section{Discussion}

The shoot count in this study was in agreement with Yoseph and Sorsa (2014) who reported counts of 3, 2.8, and 2.7 for three improved sorghum varieties at flowering growth stage. There was a significant accretion in the number of shoots from PS2 to PS3 with no significant accretion thereafter. Dual purpose sorghum varieties have inherent shoot emerging ability and the number of shoots has been reported to accrue with maturity (Gachuki et al. 2007). Number of shoots did not accrue after soft dough stage (PS2) and this might have been associated with nonproduction or dormancy of shooting buds as more energy could have been diverted to grain formation and filling.

Dry matter (DM) yield accrued as the crop got older. Accrued DM value and yield at PS3, PS4 and PS5 growth stages could be ascribed to accrue in composition of plant organs as the plant got mature. There are accrued proportions of stems, leaves, panicles and shoots and accrued grain fraction. Accrued number of shoots as the plant matures results in accrued foliage DM fraction. IDPS has inherent ability of shoot emerging and this could be associated with its accrual of DM as it matures (Ouma et al. 2013). Ability of forage crops to amass sufficient DM value is extremely important for both fresh forage feeding and ensiling (Carmi et al. 2005). Shoot emerging is an important genetic trait that affects grain yield and biomass production (Kuraparthy et al. 2008; Hammer et al. 2006). Shoot emerging in sorghum is associated with genetics, carbon supply demand (S/D) balance of the plant, or an intrinsic propensity to tiller (PTT) (Hae et al. 2010). 
Reduced DM value at PS5 might be ascribed to removal of DM fraction contained in grains after their reaping. PS6 coincided with dry spell and moisture stress yielded to stunted growth of shoots and thus a decline in DM accrual. Prolonged reaping of PS6 yielded to emergency of large proportion young shoots as the parent stalks degenerated. During reaping at PS6, the young shoots had not amassed much DM as the parent materials at PS5 and this could have contributed to reduced DM yields which were noticed at this growth stage

Reduction of CP with plant age in sorghum was in agreement with several other researchers. Ibrahim et al. (2012) reported a reduction from 9.2 from panicle emergence to 5.7 at physiological maturity growth stage. Similarly, Khan et al. (2011) reported a reduction from 7.00 to 6.00 from heading to milk growth stages respectively. Reduced CP percentages with advancing maturity might be ascribed to a reduced proportion of leaves to stem. Leaves contain high amount of CP and are the main contributor of protein in the forage (Cakmakci et al. 1999). Lower CP between PS and PS5 could be ascribed to loss of some of the protein contained in grains prior to reaping. The crude protein value of the forage at all growth stages was below $8 \%$, the minimum required to keep sufficient microbial growth in the rumen (Gregory and Felker, 1992). Addition of protein rich fodder crops, legumes and some agro-by products is recommended for sorghum basal diets in agreement with Jumaa et al. (2012). Addition induces ingestion of the forage resulting in high energy intake (Gregory \& Felker, 1992).

Accretion in NDF value with plant age was in agreement with Khan et al. (2011) who reported an accretion from $68.40,69.01$ to 71.70 of forage sorghum from pre-heading, boot and milk growth stages respectively. Ibrahim et al. (2012) reported an accretion in ADF value from 339 to $353 \mathrm{~g} / \mathrm{kg}^{-1}$ for sorghum cultivar Nes from panicle emergence to milk growth stage and ADL value from 39.2 to $44.2 \mathrm{~g} / \mathrm{kg}^{-1}$ for sorghum cultivar Nes from panicle emergence to milk growth stage respectively. Ashiono et al. (2005) reported ADF of 43.7 while Heuze et al. (2012) reported ADL of 7.4 at physiological maturity growth stages. Synthesis and accrual of fiber value as plants mature could be ascribed to formation and thickening of secondary cell walls and could also be as a result of accretion in cell wall value, lignification of stem and leaves as cellulose increases more than hemicellulose value (Ibrahim et al. 2012). NDF, ADF and ADL value at PS3, PS4 and PS5 were similar. This might be ascribed to the emergence of shoots which ameliorated the fiber value even with accretion in age through the three growth phases.

The highest ash value was in PS1, PS2 and PS3 and can be associated with rapid mineral consumption during the early stages of growth. Warrick et al. (2011) stated that about $80 \%$ of the mineral consumption by plants occurs at the flowering stage and beyond this stage its absorption is reduced drastically. Stored minerals are utilized at afterward stages of growth for various physiological processes occurring within the plant, such as grain formation. This may explicate the reduction in ash levels at afterward stages of plant growth.
Heuve et al. (2012) reported that 60.30 and 55.00 in milk and dough growth stages were comparable with IVDMD in PS2 and PS3 of 60.1 and 54.7 in this study. The decrease in IVDMD as crop senesced from PS1 to PS6 can be ascribed to leaf and stalk lignification with raised cell wall value. The increment in proportion of stems and consequently a reduction in the proportion of leaves with maturity may also lead to a reduction in IVDMD. Dissoluble solids rapidly decline and lignin and xylan augment shortly after physiological maturation (Chaudhary et al. 2012). High protein value at early growth stage can raise rumen microbial activity and thereby raise IVDMD. The resemblances in IVDMD in PS3, PS4 and PS5 can be ascribed to the resemblances of their chicks that are at the same growth stage (soft and hard dough stages). The levels of IVDMD found at all stages of growth (PS1 to PS6) were above $45 \%$ reported by Youngquist et al. (1990) for received levels to keep the weight of bovine in the tropics.

At the same growth stage, the ratoon crop system produced a higher DM result than the parent crop system. Accrued DM yields were associated with accretion in sapling after the first cutting. Cutting off the main stem stimulates the emergence of the basal node (Ashiono et al. 2005) while the application of manure after cutting increases the sapling emergence of the basal node (Gachuki et al. 2007). The nutritional value of ratoon plants and parent plants was similar and this can be ascribed to similar morphological changes in growth between ratoon and parent plants. Ratoon crop reaped in bloom stage (PS1) amassed no DM and nutrients and should be allowed to grow beyond this growth stage and might be reaped in hard dough stages to make a balance in DM yield and quality.

In conclusion, DM harvests of IDPS accrued with the increase of reaping age while forage quality decreases with increasing age. The balance between quality and quantity is gained at reaping time within 142 to 169 days. It is recommended that the optimal time for the use of IDPS as animal feed should be inside the time of hard dough to physiological grain maturity growth stage. Protein supplementation was needed since CP value in IDPS was low. The ratoon crop of IDPS produced a higher DM than the mother crop and farmers should be encouraged to allow for ratooning.

\section{ACKNOWLEDGEMENTS}

We thank Kenya Agricultural and Livestock Research Organization (KALRO) for financing the study, Animal Nutrition Laboratories at KALRO Lanet, KALRO Naivasha and the University of Nairobi, Kenya for preliminary samplings and consequent feed analysis, Peter Gachuki and Dr. Samuel Mbuku for sharing some knowledge on sorghum and livestock production respectively, and James Kinyua of Chuka University, Ndagani, Kenya for his guidance in statistical data analysis 


\section{REFERENCES}

AOAC. 1990. Official Methods of Analysis. 13th ed. Hoerwitz W. (ed) Association of Analytical Chemists. Washington D.C., U.S.A

Ashiono GB, Ouda JO, Akuja TE, Kitilit JK, Irungu KG, Gatwiku S. 2012. Effect of potato vines and sorghum silage on cattle milk productivity. Asian J Plant Sci 5 (1): 81-84. DOI: 10.3923/ajps.2006.81.84

Cakmakci S, Gunduz, S, Cecen, Aydinoglu B. 1999. Effects of different reaping times on yield and quality of sorghum silage (Sorghum bicolor L.). Turkish J Agric For 23: 603-611.

Carmi A, Nakdimon U, Amir H, Edith Y, Daniel B, Miron J. 2005. Field performance and nutritive value of a new forage sorghum variety 'Pnina' recently developed in Israel. J Sci Food Agric 85: 2567-2573. DOI: $10.1002 /$ jsfa.2299

Chaudhary DP, Kumar A, Sapna S, Srivastava P, Kumar RS. 2012. Maize as fodder? An alternative approach. 12th Asian Maize Conference and Expert Consultation on Maize for Food, Feed, Nutrition and Environmental Security 30 October - 1 November 2014, Bangkok, Thailand

Gachuki, PN Githui PM, Onyango TA, Kirui J. 2007. World Agroforestry Centre (ICRAF, EADD leaflet no. 4). World Agroforestry Centre, Nairobi, Kenya.

Gregory, R A, Felker, R, P. 1992. Crude protein and phosphorus contents of eight contrasting Opuntia forage clones. J Arid Environ 22 (4) 323-331. DOI: 10.1016/S0140-1963(18)30574-3

Hae K K, Luguet D, Van Ooterom E, Dingkuhn M, Hammer G. 2010. Regulation of shoot emerging in sorghum genotypic effects on yields and forage quality. J Anim Sci 46: 2114-2056.

Hammer GL. 2006. Pathways to prosperity; breaking the yield barrier in sorghum. Agric Sci 19: 16-22.

Heuzé V, Tran G, Giger-Reverdin S, Lebas F. 2012. Sorghum forage. Feedipedia, a programme by INRA, CIRAD, AFZ and FAO https://www.feedipedia.org/node/379

Ibrahim A, Omer K, Metin D, Huseyin G, Saban Y. 2012. Effect of Reaping Time on Yield, Composition and Forage Quality of Some Forage Sorghum Cultivars. Department of Field Crops, Faculty of Agriculture, Mustafa Kemal University, Hatay, Turkey.

Irungu KR, Ashiono GB, Muchemi J. 1993. Effect of age on chemical composition of forage and grain sorghum, National sorghum and millets programme, Kenya Agricultural Research Institute (KARI)Lanet City, Nakuru Country, Kenya.

Jumaa B, Mohammed A, Ali M, Ahmed M, Tibul M. 2014. Effects of chopping and supplementation of sorghum straw on feed intake, hematological parameters and performance of desert goats in EINuhud, North Kordofan, Sudan. University of Kordofan, Sudan.

Khan SH, Azim A, Sarwar M, Khan AG. 2011. Effect of maturity on comparative nutritive value and fermentation characteristics of maize, sorghum and millet silages. Pak J Bot 43 (6): 2967-2970.

KMDP. 2013. Kenya Market-led Dairy Programme" (KMDP) of SNV/Kenya Netherlands Development Organisation (KMDP 2013)

Kuraparthy V, Gill BS. 2008. Genomic targeting and mapping of shoot inhibition gene of wheat using ESTs and synteny with rice. Funct Integr Genom 8: 33. DOI: 10.1007/s10142-007-0057-4

Le Van A, Bodil E, Francow L, Linberg JE. 2003. Effect of reaping intervals and ratooning on yield and chemical composition of leaves, stems and storage roots of sweet potato plant parts. Field Crop Res 82: 49-58. DOI: 10.1016/S0378-4290(03)00018-2

Nandwa JM. 2013. The impact of Land Fragmentation/Segmentation on Production and Food Security (Case study: Three major regions in Kenya). School of Business and Management Sciences, Chepkoilel University College-a constituent college of Moi University, Eldoret, Kenya.

Ouma A. 2013. Agronomic and morphological performance of sorghum for dry highlands of Kenya 4720, Agronomic and morphological performance of sorghum (Sorghum bicolor L.) for the dry highlands of Kenya. J Appl Biosci 63: 4720-4726. DOI: 10.4314/jab.v63i1.87246

Shem MN, Mtengeti EJ, Lunga M, Ichinohe T, Fujihura T. 2001. Feeding value of wild Napier grass (Pennisetum macrourum) for cattle supplemented with protein and/or energy rich supplements. Anim Feed Sci Technol 108 (1-4): 15-24. DOI: 10.1016/S03778401(03)00167-6

Tilley JM, Terry RM. 1963. A two stage technique for the in vitro digestion of forage crops. J Br Grassland Soc 18: 104-111. DOI: 10.1111/j.1365-2494.1963.tb00335.x

Van Soest PJ, Robertson JB, Lewis BA. 1991. Methods for dietary fiber, neutral detergent fiber, and nonstarch polysaccharides in relation to animal nutrition. J Dairy Sci 74: 3583-3597. DOI: 10.3168/jds.S00220302(91)78551-2

Warrick, B, E. 2011. How sorghum plant develops. Texas A\&M AgriLife Research and Extension Center, San Angelo, USA.

Yoseph T, Sorsa Z. 2014. Evaluation of sorghum (Sorghum bicolor (L.) Moench) varieties, for yield and yield components at Kako, Southern Ethiopia. J Plant Sci 2 (4): 129-133. DOI: 10.11648/j.jps.20140204.12

Youngquist J. B, Carters D. C. and Clegg M. D. 1990. Grain and forage yield and stover quality of sorghum and millet in low rainfall environment. Exp Agric 26: 279-286. DOI: 10.1017/S0014479700018433 